\title{
Joseph Henry: letters from America
}

\section{Colin Russell}

The Papers of Joseph Henry, Vol. 4: January 1838-December 1840, The Princeton Years. Edited by Nathan Reingold. Pp.475. ISBN 0-87474-792-9. (Smithsonian Institution Press, Washington DC: 1981.) $\$ 30$.

JoSEPH Henry (1797-1878) was an American physicist and a researcher in electricity and magnetism. He had the misfortune to be a contemporary of Faraday by whom he has been considerably overshadowed; even when he emerges from the penumbra of the great Englishman he is not seen as a major luminary in science, and one may wonder at the colossal expenditure of labour in this reprinting of his papers. If it may not be justified in terms of Henry's inherent scientific stature, the rationale would appear to lie in his position within the community of early nineteenth-century science, particularly in America. He knew almost everyone of importance on both sides of the Atlantic, and such people flit effortlessly in and out of his correspondence. To read his papers is to gain a richer understanding of the social milieu in which Henry lived and much of modern physics took shape.

During most of the period covered by this book (1838-1840) Henry's life was fairly uneventful, concerned mainly with his family at home or seriously fulfilling his calling as Professor of Natural Philosophy at Princeton. For this reason the present volume lacks something of the punch and zest of its predecessor (for review see Nature 286, 311; 1980), which dealt mainly with his grand tour of Europe. However there are compensations, and a large proportion of the book is concerned with his "records of experiments" from manuscript material. Some of his work was over-hasty as he wished to establish priority over Faraday, but here is an unselfconscious record of one man working under great pressure to unravel the complex phenomena of electromagnetism. Amongst his most significant discoveries of this time was that of electric induction across great distances, leading him to take the side of those who advocated an allpervasive ether, thus anticipating in certain respects the more comprehensive theories of Maxwell.

In the correspondence a note that constantly reappears is that American science must at all costs be protected from the quacks and the charlatans (amongst whom he numbers the egregious Samuel Morse). In this respect New York was worse than Philadelphia, but the danger was endemic in a small beleaguered community of science that lacked the checks and balances of its older European counterparts. Much could be learned from Europe, of course, and America had its English-sounding Society for the
Promotion of Useful Arts, while the American Association for the Advancement of Science was consciously modelled on the British equivalent. But Henry (who had been unfairly savaged at a BAAS meeting a few months earlier) very much preferred a meritocracy of science to the arrangements in Britain, in which "wisdom" and "ignorance" were mixed and where the Society was "quite as aristocratical as the government of the nation". Thus we are offered a view of British science which is rather different from that purveyed by the popularizers and promoters in Britain itself.

As in previous volumes of this series there is a short introduction, very full footnotes (which include indications of variant readings) and an excellent index. Diagrams are reproduced in facsimile and there are several pages of portraits and illustrations. One or two editorial statements raise an eyebrow here and there (for example that the preparation of magnesium was "first reported" in 1831) and on p.310 two lines have been transposed. However, as we have come to expect, the standard of production is generally superb, with the luxury of footnotes at the bottom of the page or at the end of each document. When several publishers are charging twice as much for shorter works, with much less lavish presentation, this book is a rare bargain for all concerned with history of nineteenthcentury physical science.

Colin Russell is Professor of History of Science and Technology at the Open University. His most recent book, Science and Social Change, will be published by Macmillan, London, later this year.

\section{Standard methods in geomorphology}

\section{Kidson}

Geomorphological Techniques. Edited by Andrew Goudie. Pp.416. Hbk ISBN 0-004551022-3; pbk ISBN 0-004-551043-1. (George Allen \& Unwin: 1981.) Hbk £25, $\$ 60$; pbk £12.95, \$29.95.

GEOMORPHOLOGY, the science which seeks to understand the processes which shape the surface of the Earth, lies in the borderland between geography and geology. In the United States it is firmly based in geology. In Europe, however, most of the recent major developments in the subject have, by and large, been the work of physical geographers. The British Geomorphological Research Group, for whom this volume is edited, have, as a subject group of the Institute of British Geographers, been in the forefront of research in this field. Thus it is entirely appropriate that an attempt to bring together those techniques, both field and laboratory, most appropriate to the discipline should emanate from this active and distinguished group of geographers. In a sense, the book is a natural development from their successful series of Technical Bulletins, two-thirds of which are referred to in the text. It does, however, go well beyond the scope of that series.

A prime objective of a "manual of useful techniques" should be to provide a work of reference for those who wish to improve their technical repertoire. Kummel and Raup's Handbook of Palaeontological Techniques (W.H. Freeman, 1965) is an example of what can be achieved. In its better sections, Geomorphological Techniques matches the high standards set in that volume - Parts 3 (Material Properties) and 4 (Process) are as useful and authoritative summaries as the readers of the book could hope to find. In others, however, notably the first two parts on form and time, the techniques are enclosed in a matrix of theory and philosophy which suggest a textbook rather than a manual. In falling between two stools the value of these parts is reduced.

Inevitably, in a volume arranged on the basis of form, materials, process and time, and written by more than 30 authors, there are some techniques which have been inadequately dealt with or even omitted. Topographic survey methods such as levelling are superficially treated. Plane tabling, which one would have thought to be basic to students of landforms, is totally omitted. The collection of samples with the aid of augers, corers and drills is scarcely mentioned, with the notable exception of the section on glacial processes and that on peats and lake sediments. In addition, the coverage of tracer techniques is woefully inadequate.

Surprisingly, for a work of this calibre, there are some remarkably superficial statements. On p.8, for example, it is asserted that "During the predominance of denudation chronology, data acquisition was dominated largely by qualitative field observations and subjective map analysis"'. No one who had been in the field with Wooldridge or Cotton, or who had attended a class in cartographic analysis with Hollingsworth, could conceivably have made such such a meaningless generalization.

Despite its imperfections this is a useful contribution to this vigorously growing science. It is the best available comprehensive treatment of the subject and is destined to be the standard work for some time to come.

C. Kidson is Professor of Physical Geography and Head of the Department of Geography at the University College of Wales, Aberystwyth. 